\title{
MALI VODNI TOKOVI IN NJIHOVO POPLAVNO OGROŽANJE LJUBLJANE
}

\section{Zbirka GeograFF I0. Znanstvena založba Filo- zofske fakultete in Oddelek za geografijo, II9 str. Ljubljana, 20II}

Druga monografija iz serije GeograFF v letu 2011 prinaša rezultate interdisciplinarne aplikativne raziskovalne naloge 'Sanacija malih vodnih tokov in ukrepi za zmanjšanje poplavne ogroženosti Ljubljane', ki jo je financirala Mestna občina Ljubljana. Glavni namen raziskave je bil, da se ugotovi, v kolikšni meri mali vodotoki na območju mestne občine ogrožajo prebivalstvo in njihove dobrine

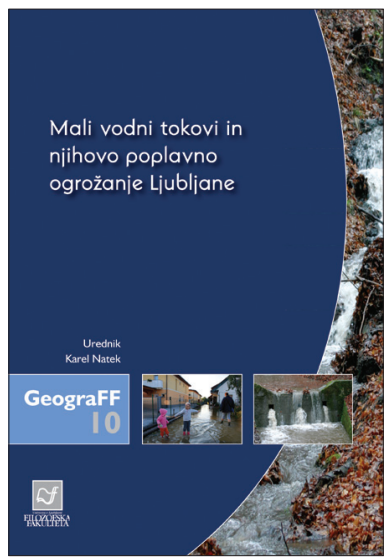
in kako bi bilo možno stanje na tem področju izboljšati.

Ta problematika je bila doslej 'v senci' hujše grožnje poplav Ljubljanice in Gradaščice v južnem delu Ljubljane in drugih naselij na Ljubljanskem barju, vendar tudi v dolinah potokov, ki pritekajo z Golovca in drugih, večinoma gozdnatih hribovij, naravnost v urbaniziran mestni prostor, ta nevarnost nikakor ni nezanemarljiva.

S problemom hudourniških poplav ob malih vodotokih se je soočila interdisciplinarna raziskovalna skupina, ki so jo sestavljali raziskovalci z Oddelka za geografijo Filozofske fakultete (Karel Natek, Irena Mrak, Darko Ogrin, Uroš Stepišnik), dva raziskovalca z Inštituta Republike Slovenije za vode (Aleš Bizjak, Petra Repnik Mah) in sodelavca podjetja Limnos, d.o.o. (Danijel Vrhovšek, Darja Istenič).

Ključne ideje projekta so bile:

- ukrepi za zmanjševanje poplavne ogroženosti so nujni zlasti na ugotovljenih kritičnih točkah;

- hkrati s temi ukrepi je treba v smislu evropske vodne direktive vodotoke vrniti nazaj v t.i. dobro ekološko stanje;

- ureditve izpeljati tako, da s tem izboljšamo oziroma obogatimo bivalno okolje okoliških prebivalcev;

- $\quad$ pri poseganju uporabimo že preverjene in učinkovite ukrepe ekoremediacije.

Vsebina knjige je razdeljena na osem poglavij, v katerih so med drugim predstavljene splošne značilnosti malih vodotokov na območju mestne občine (I. Mrak), maksimalne možne kratkotrajne padavine v Ljubljani (D. Ogrin), maksimalni možni pretoki na malih vodotokih (U. Stepišnik), opisi stanja in poplavne ogroženosti na malih vodotokih (K. Natek), predlogi ukrepov za zmanjšanje poplavne ogroženosti ob teh vodotokih (A. Bizjak, P. Repnik Mah) ter predlogi za njihovo sanacijo in ukrepov za zmanjšanje poplavne ogroženosti (D. Vrhovšek, D. Istenič).

Na osnovi meteoroloških podatkov za postajo Ljubljana-Bežigrad so bili izračunane najvišje možne višine padavin, ki lahko v Ljubljani padejo v eni, šestih, 12 in 24 urah, na osnovi teh podatkov in značilnosti porečij malih vodotokov pa še njihovi največji možni 
pretoki. Podatki o teh pretokih so zaskrbljujoči, saj prikazujejo sicer majhne potoke v povsem drugačni luči - kot grozeče hudournike. Ti lahko ob močnih padavinah dosežejo pretoke več deset kubičnih metrov na sekundo, teh pa dosedanje ureditve (betonska korita, improvizirani in premajhni ter nevzdrževani vtoki, premajhni podzemni kanali, gradnja tik ob strugah ali celo nad njimi, idr.) nikakor ne bi mogli prevajati in bi lahko nastale sicer lokalno omejene, vendar nevarne hudourniške poplave.

V preučevanje je bilo zajetih 14 malih vodotokov na območju mestne občine, predvsem na močno urbaniziranem južnem in severnem vznožju Golovca ter na obrobju hribovitega sveta $\mathrm{v}$ vzhodnem delu mestne občine, vključno z največjima hudournikoma, Javorniško reko in Besnico.

Zaključni poglavji prinašata analizo evidentiranih kritičnih točk na preučevanih vodotokih s seznamom možnih negradbenih ukrepov za zmanjšanje poplavne nevarnosti. Za razliko od prevladujoče dosedanje prakse bi se lahko večjim gradbenim posegom v struge vodotokov skoraj povsem odrekli, namesto teh pa uporabili v zadnjem poglavju predstavljen nabor ekoremediacijskih ukrepov, ki jih je možno uporabiti tudi v omejenem, močno urbaniziranem mestnem prostoru (odbijači, umetne zajede, umetni meandri, pragovi, manjša mokrišča v poplavni ravnici, obrežna vegetacija, ipd.). Zlasti pri vodotokih v vzhodnem delu mestne občine, ki so zaenkrat še v razmeroma dobrem ekološkem stanju in so ob njih do danes ostale delujoče poplavne ravnice s travniki, pa je najpomembneje, da se ta območja ohranijo v obstoječem stanju in funkciji in da se prepreči širjenje urbanizacije na ta nevarna, a ekološko, rekreacijsko in estetsko izjemno pomembna območja.

Karel Natek 